\title{
Brain Banks and Tissue Repositories for Blast-Related Chronic Traumatic Encephalopathy Research
}

\author{
Chandler Sours, Sidney R. Hinds II, Ann C. McKee,,4 Daniel P. Perl,, and Michael J. Leggieri Jr²
}

A T THE CONCLUSION of the 2015 International State-of-theScience (SoS) Meeting on "Does Blast-Related Trauma Contribute to the Development of Chronic Traumatic Encephalopathy (CTE)?," organized by the Department of Defense (DoD) Blast Injury Research Program Coordinating Office, the Expert
Panel identified a critical knowledge gap: blast exposed tissue, with well-annotated medical and blast exposure histories available for neuropathological analysis, are lacking. This finding led to the Expert Panel's highest priority recommendation, which was to create a coordinated brain bank and tissue repository system with a robust

Table 1. Detailed Information on Brain Repositories

\begin{tabular}{|c|c|c|c|}
\hline & $\begin{array}{l}\text { CNRM Brain } \\
\text { Tissue Repository }\end{array}$ & $\begin{array}{l}V A-B U-C L F \\
\text { Brain Bank }\end{array}$ & $\begin{array}{c}\text { CENC Brain } \\
\text { Tissue Biorepository }\end{array}$ \\
\hline Establishment & $\begin{array}{l}\text { Established in } 2010 \text { at USUHS in } \\
\text { Bethesda, MD, through funding } \\
\text { from the Department of Defense. }\end{array}$ & $\begin{array}{l}\text { The VA-BU-CLF Brain Bank was established } \\
\text { in } 2008 \text { at the Edith Nourse Rogers Memorial } \\
\text { Veterans Hospital in Bedford, MA; the brain bank } \\
\text { moved to VA Boston in } 2016 .\end{array}$ & $\begin{array}{l}\text { The CENC Brain Tissue } \\
\text { Biorepository was established in } \\
\text { July } 2016 \text { at VA Boston } \\
\text { Healthcare System. }\end{array}$ \\
\hline Mission & $\begin{array}{l}\text { Through the repository, scientists } \\
\text { and physicians will use innovative } \\
\text { approaches to better understand } \\
\text { traumatic brain injury (TBI) in } \\
\text { Service Members and how to care } \\
\text { for our military personnel after a } \\
\text { head injury. }\end{array}$ & $\begin{array}{l}\text { To collect and study post-mortem human brain, eyes, } \\
\text { and spinal cord tissue from individuals exposed to } \\
\text { concussive and subconcussive injury or blasts in } \\
\text { order to better understand the acute and long-term } \\
\text { effects of repetitive mild or blast trauma on the } \\
\text { human nervous system, and to develop biomarkers } \\
\text { and effective treatments. }\end{array}$ & $\begin{array}{l}\text { To collect and study post-mortem } \\
\text { human brain, eyes, and spinal } \\
\text { cord tissue from military Veterans } \\
\text { exposed to concussive and } \\
\text { subconcussive injury or blasts in } \\
\text { order to better understand the } \\
\text { acute and long-term effects of } \\
\text { repetitive mild or blast trauma on } \\
\text { the human nervous system, and to } \\
\text { develop biomarkers and effective } \\
\text { treatments. }\end{array}$ \\
\hline Population & $\begin{array}{l}\text { Military Service Members, with and } \\
\text { without blast exposure. }\end{array}$ & $\begin{array}{l}\text { Professional and amateur athletes with exposure to } \\
\text { repetitive head impacts, military personnel or } \\
\text { Veterans with exposure to blast injury or concussive } \\
\text { injury, civilians exposed to repetitive concussive or } \\
\text { subconcussive or blast injury. }\end{array}$ & $\begin{array}{l}\text { Military Veterans with exposure to } \\
\text { blast injury or concussive and } \\
\text { subconcussive injury. }\end{array}$ \\
\hline Director & Dr. Daniel Perl & Dr. Ann McKee & Dr. Ann McKee \\
\hline Website & $\begin{array}{l}\text { http://www.researchbraininjury } \\
\text {.org/ }\end{array}$ & https://www.bu.edu/cte/our-research/brain-bank/ & $\begin{array}{l}\text { https://cenc.rti.org/About/Donate- } \\
\text { Your-Brain }\end{array}$ \\
\hline Contact & $\begin{array}{l}\text { 855-366-8824; or http://www } \\
\text {.researchbraininjury.org/contact- } \\
\text { us }\end{array}$ & $\begin{array}{l}\text { Bobak Abdolmohammadi; Research Assistant; 617- } \\
\text { 414-1184 bobdolmo@bu.edu; or Laney Evers: 617- } \\
\text { 414-1187; levers@bu.edu }\end{array}$ & $\begin{array}{l}\text { Hannah Gardner: 857-364-5694; } \\
\text { Hannah.Gardner@va.gov; } \\
24 \text { hour phone line: } \\
\text { 617-276-6023 }\end{array}$ \\
\hline
\end{tabular}

CRNM, Center for Neuroscience and Regenerative Medicine; VA-BU-CLF, Veterans Affairs-Boston University-Concussion Legacy Foundation; USUHS, Uniformed Services University of the Health Sciences; CENC, Chronic Effects of Neurotrauma Consortium.

\footnotetext{
${ }^{1}$ Booz Allen Hamilton, McLean, Virginia.

${ }^{2}$ Department of Defense Blast Injury Research Program Coordinating Office, United States Army Medical Research and Materiel Command, Fort Detrick, Maryland.

${ }^{3}$ VA Boston Healthcare System, Boston, Massachusetts.

${ }^{4}$ Center for the Study of Traumatic Encephalopathy, Alzheimer's Disease Center, and Department of Neurology, Boston University School of Medicine, Boston, Massachusetts.

${ }^{5}$ Brain Tissue Repository and Neuropathology Care, Center for Neuroscience and Regenerative Medicine, Uniformed Services University of the Health Sciences, Bethesda, Maryland.

${ }^{6}$ Department of Pathology, F. Edward Hébert School of Medicine, Uniformed Services University of the Health Sciences, Bethesda, Maryland.
} 
plan for donation of clinical specimens that are annotated with thorough medical and blast exposure data that would enable exploration of the relationship between CTE neuropathology, risk factors and clinical features. This systemic approach including well-annotated medical and blast histories to accompany the corresponding tissue sample(s) is critical for unraveling the nature of the relationship and rule in or out causality of exposure to CTE pathology.

One current DoD initiative addressing this recommendation is the Brain Tissue Repository at the Center for Neuroscience and Regenerative Medicine (CNRM) at the Uniformed Services University of Health Sciences (USUHS) under the leadership of Dr. Daniel Perl. In addition, the United States Department of Veterans Affairs (VA) supports the Chronic Effects of Neurotrauma Consortium (CENC) Brain Tissue Biorepository in collaboration with the DoD and supports the Veterans Affairs-Boston University-Concussion Legacy Foundation (VA-BU-CLF) Brain Bank at the VA Medical Center, Boston. Both brain banks are under the leadership of Dr. Ann McKee. Table 1 provides detailed information on each repository.

Although the DoD and VA have made numerous strides in addressing this Expert Panel recommendation, multiple challenges remain. For example, brain banks and repositories must improve methodologies regarding how to properly collect brain donations in a time sensitive and efficient manner that are ethical and respectful of those who have died and sensitive to the loss experienced by the deceased's loved ones. Furthermore, additional work must be done to spread awareness of these brain tissue repositories and inform Service Members, Veterans and athletes of the options and mechanisms to make donations. The successful efforts to understand the relationship between repetitive TBI, blast, and CTE depends on the support of refined and optimized policies which enable those willing to donate brains and tissues to do so seamlessly. This will allow a stream-lined and effective means of donation which will advance our understanding of blast-related brain injury.

Address correspondence to: Sidney R. Hinds II, MD Department of Defense Blast Injury Research Program Coordinating Office United States Army Medical Research and Materiel Command 504 Scott Street Fort Detrick, MD 21702

E-mail: sidney.r.hinds.mil@mail.mil 